\title{
Engineering geology and geotechnical characterization of Tabriz Metro Line 2, Iran
}

\author{
Ali Alizadeh $^{1}{ }^{\mathbb{C}} \cdot$ Souheila Buzari ${ }^{1} \cdot$ Yousef Sattarzadeh $^{2} \cdot$ Mohsen Pourkermani $^{1}$
}

Received: 25 November 2020 / Accepted: 24 March 2021 / Published online: 1 April 2021

(c) The Author(s) $2021 \quad$ OPEN

\begin{abstract}
The present study was performed in order to determine the engineering geology and geotechnical details of soils and rocks along Tabriz Metro Line 2(TML2) by using the information and raw data which were acquired by borehole drilling and all field and laboratory tests in the study area. The minimum and maximum depths of the boreholes were 15 and $40 \mathrm{~m}$, respectively. The results of their analysis revealed that geologically, the areas of metro route, mainly formed by alternating layers of claystone, siltstone, marl, and conglomerate, covered mainly by the alluvial deposits and in addition to older, dextral, strike-slip North Tabriz Fault (NTF) which is a major and most important geological structure of Tabriz area, there are also many minor and generally young and seismically active faults. The results of investigation on the groundwater depth in boreholes of TML2 also indicated that the groundwater depth varies between 1.5 and $30 \mathrm{~m}$, along the route of metro. Eventually, based on the standard penetration test values (N-SPT), it was revealed that soils of the western parts of TML2 are in the group of dense to very dense, the central parts are in the group of very dense (Bazaar area) and dense (Fahmideh area), and the eastern parts are very dense. And finally the results achieved from determining groundwater sulfate values according to Concrete Code of Iran (CCI) indicated that the amount of soluble sulfate in the soil is mild to extremely high. Accordingly, the amount of sulfate increases from the western to the eastern parts. So that, this value is between 200 and 26,500 ppm. Based on these studies, the average of sulfate in the western, central and eastern parts is, respectively, 1118, 1275 and $4840 \mathrm{ppm}$. Thus, the groundwater in the east part is highly aggressive, and deterioration of concrete lining of the tunnel is expected in the near future.
\end{abstract}

Keywords Geotechnical specifics · Sediments · Ground water level · Tabriz Metro Line 2

\section{Introduction}

At the present time, heavy traffic of urban transportation is one the most important problems of large cities and as it has been experienced in many large cities around the world, the use of underground transportation, called as metro, is the best and most useful way of solving this problem. Geotechnical studies are the most important and fundamental investigations for construction of underground tunnels of Metro Lines. These studies generally are carried out for designing the type and shape of tunnels, and determining geotechnical properties of rocks and soils, as well as, the type of required tunnel drilling machine and the best method of tunnel excavation. Construction of tunnels is usually a difficult task because information about the ground conditions is never completely known, during tunneling. Construction cost estimation of tunnel is also difficult task due to the complexity of the ground conditions [18]. However, engineering geology along the tunnel alignment plays a dominant role in many of the major decisions that must be made in planning, designing and construction of a tunnel. Thus, it is vital to conduct

Ali Alizadeh, alizadeh_ali64@yahoo.com | ${ }^{1}$ North Tehran Branch, Islamic Azad University, Tehran, Iran. ${ }^{2}$ Tabriz Branch, Islamic Azad University, Tabriz, Iran. 
appropriate engineering geological investigations prior to any planning process for the construction of tunnels.

Several researches have been performed for evaluating the engineering geology and geotechnical characteristics of structural projects such as subway tunnels, including: Delezalova [19] researched the approaches in numerical modeling of ground movements due to shallow tunneling. Ozsan et al. [32] carried out the engineering geological investigations along the Ankara Metro. Also, Leca and New [29] discussed about the settlements induced by tunneling in soft ground. Ghiasi et al. [22] have surveyed about the subway station seismic consideration based on geotechnical study in metro station of Tehran (Iran). Azali et al. [2] conducted the engineering geological investigations of mechanized tunneling in soft ground in the East-West lot of line 7 of Tehran Metro in Iran. Furthermore, Golpasand and Nikoudel [21] evaluated the effect of engineering geological characteristics of Tehran's recent alluvial on ground settlement due to tunneling. Mitew-Czajewska [30] studied the geotechnical investigation and static analysis of deep excavation walls in the construction of Warsaw metro station. In the study performed by Sadjadi and Bagherzadeh Khalkhali [38] the Geotechnical Challenges of Tehran Metro Line 7 were evaluated. Eventually, Azarafza et al. [4] have carried out the stochastic geometry model of rock mass fracture network in the Kani-Sib tunnel in the northwest of Iran. Also, Cueto et al. [16] researched the Karst detection, prevention and correction in the line 3 of Riyadh Metro (Saudi Arabia). Beside, recently other important studies have been performed by Cueto et al. [17] in the field of engineering geological assessment using geochemical, mineralogical, and petrographic analysis along the Riyadh Metro Line 3 (Saudi Arabia).

In this research, engineering geology and geotechnical studies include the study of drilled boreholes, physical characteristics of existing soils and rocks layers and groundwater depth, on the basis of results acquired from Standard Penetration Test (SPT), and the chemical characteristics of soils such as the amount of existing sulfate of soils of the drilled boreholes, along the route of line 2 of Tabriz metro have been analyzed. Study area Tabriz Metro Line 2 was selected. According to the development plan of the Tabriz subway, four Metro Lines will be built in the near future. The construction of Line 2 with a length of $22 \mathrm{~km}$ has currently started. The total length of TML2 will be excavated by EPB-TBM1, and the depth of the tunnel ranges from 9 to $26 \mathrm{~m}$ from the ground surface [25]. For study area, different researches about geotechnical properties and engineering geology have been carried out, for example: Ghobadi et al. [23] studied the relationships between geological formations and groundwater chemistry and their effects on the concrete lining of tunnels in Tabriz Metro Line 2. Babazadeh et al. [10] and Mohammad et al.
[31] evaluated the engineering geological investigations along the Tabriz subway extension focusing on ground surface settlement and geological-geotechnical risk in the use of EPT-TBM, respectively. Moreover, Barzegari et al. [11] performed investigations on geotechnical aspects for TBM specification on the Tabriz Metro Line 3. Eventually, Ghasemian et al. [24] and Oshnaviyeh and Dabiri [34] have researched the Settlements Hazard of Soil Due to Liquefaction and the comparison of Standard Penetration Test (SPT) and Shear Wave Velocity (Vs) method in determining risk of liquefaction potential along TML2, respectively.

In continuation, first geology and general conditions of study have been described. Second, manners used for this researches have been expressed. Then, results of analysis have been presented.

\section{Materials and methods}

In the present study, the 1:100,000 scale, geological map of Tabriz area [3], the achieved data from 53 boreholes (Borehole Log) and 15 test pits (Test Pit Log), (See Fig. 1), as well as, the obtained data from determining sulfate contents of groundwater collected from 53 boreholes were used [33, 39]. The minimum and maximum depths of the boreholes were 15 and $40 \mathrm{~m}$, respectively. Many in situ tests such as the PMT, SPT and CPT were performed within the boreholes that were drilled along the TML2. Also, groundwater samples were collected from 53 boreholes along TML2 for determining the impact of geological formations on the groundwater quality. Then, the zoning of boreholes of TML2 in terms of the amount of soluble sulfate was analyzed. In the Table 1 number of test, testing depth and test method that performed in along the TML2 has been described.

\subsection{Study area}

The metropolis of Tabriz is the capital city of East Azerbaijan Province in the northwest of Iran between the latitude of $38^{\circ} 00^{\prime}$ and $38^{\circ} 30^{\prime} \mathrm{N}$ and the longitude of $46^{\circ} 00^{\prime}$ and $46^{\circ} 30^{\prime}$ E covering about $325 \mathrm{~km}^{2}$ of the land (Fig. 2). The general topography of this area indicates that Tabriz itself lies on a vast plain with a general and gentle slope toward the west and relatively higher and NW-SE trending mountains in the northeast, as well as relatively lower and peripheral hills of Sahand volcano in the southwest of Tabriz. In addition, the seasonal Mehran Chay River runs in an E-W direction in the middle of the city. The drainage direction of surface and underground waters within the plain of Tabriz is generally toward the Mehran Chay River. Engineering and geotechnical studies for designing and constructing Tabriz Metro initiated in 2015 [33]. 


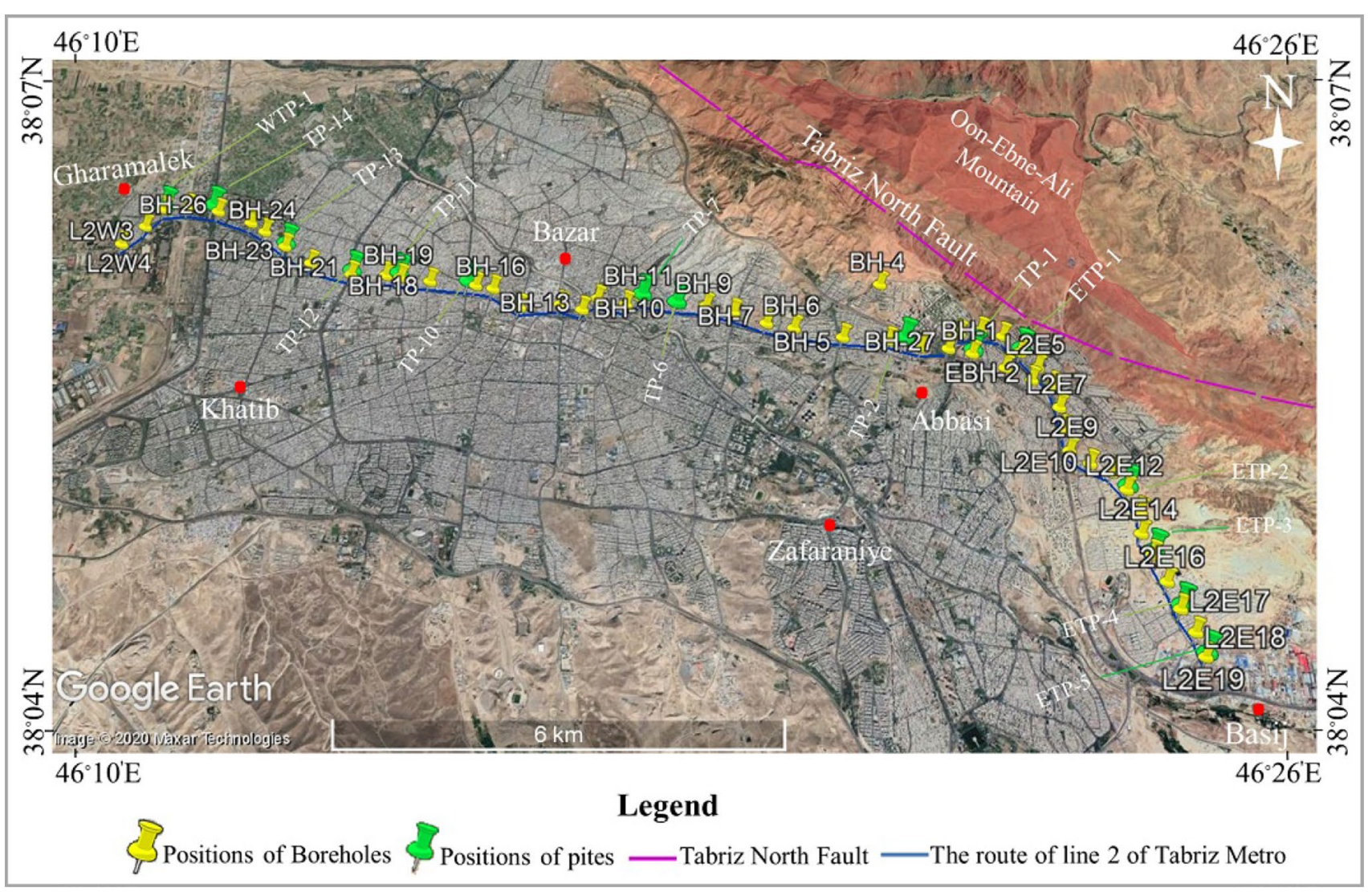

Fig. 1 Position of drilled pits and boreholes at the stations of Line 2 of Tabriz metro on satellite image (Authors)

Table. 1 Type and number of in situ testing performed in along the TML2 [33 and 39]

\begin{tabular}{llll}
\hline Test method & $\begin{array}{l}\text { Testing depth } \\
(\mathrm{m})\end{array}$ & $\begin{array}{l}\text { Number of } \\
\text { tests }\end{array}$ & In situ test \\
\hline ASTM D4719 & $5-40$ & 64 & PMT \\
ASTM D1586 & $5-40$ & 220 & SPT \\
ASTM D3441 & $3-25$ & 5 & CPT \\
\hline
\end{tabular}

The network of Tabriz Metro contains four lines with a total length of about $100 \mathrm{~km}$. Line 2 of this Metro runs about $22.4 \mathrm{~km}$ from Basij Square in the eastern margin of Tabriz to the main railway station in its western margin and includes 20 stations. This line will pass through the crowded parts of the city, notably, the business districts. The entire route will be situated underground where most parts of TML2 are covered by alluvial soils (Fig. 2).

\subsection{Geological setting}

Tabriz Metropolis with an average height of $1340 \mathrm{~m}$ above the sea level forms part of a vast westward sloping plain and is mainly covered by alluvial deposits. For study area, different researches about the general geological characteristics have been carried out, for example, according to studies of Reben [37], the mountains in the northeastern side of Tabriz metropolis mainly formed by Middle Miocene Upper Red Formation (URF), including alternating layers of red sandstone and marl with some thinner layers of conglomerate, gypsum and salt. Also, Reben [37] showed in his studies the thickness of alluvium varies in the margin and center of the Tabriz plain and is approximately between 50 and $100 \mathrm{~m}$. Based on the studies of Babakhani et al. [14] Pliocene lake sediments have generally occupied the new alluvium of Tabriz city. The thickness of this formation is very significant in some places. These sediments are composed of marl and gray clays with very soft sands. Agha-Nabati [5] believes that Tabriz city is totally covered with recent alluvial sediments and the conglomerate, sandstone and marl layers are there under the mentioned alluvial sediments. Furthermore, according to Azarafza and Ghazifard investigations [6] Tabriz metropolis and surrounding areas have been composed of young and unconsolidated deposits of mostly rivers and glacial sediments belong to Cenozoic and Quaternary formations with different textures and grading. However, the peripheral hills of Sahand volcano on the southern side of 


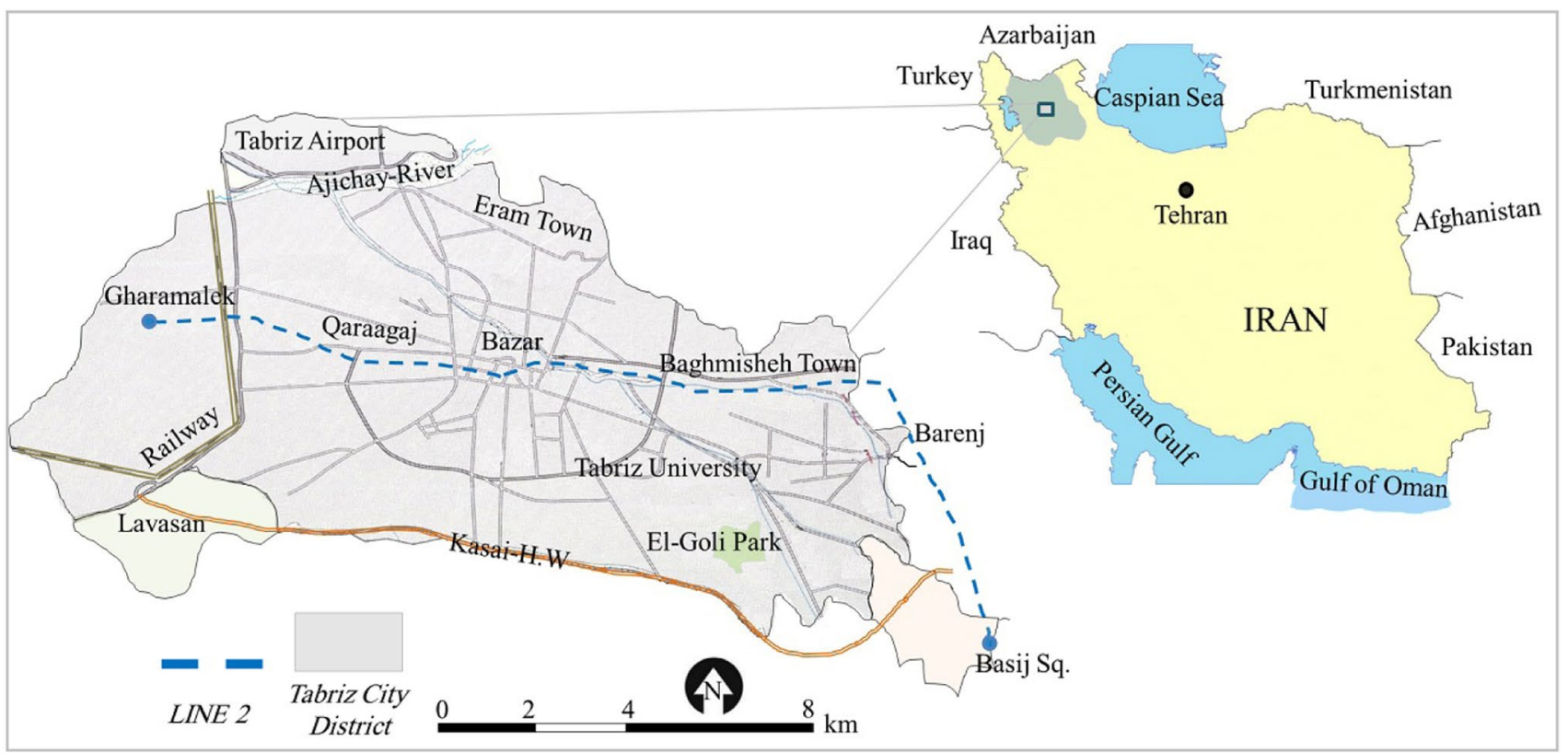

Fig. 2 Location of the study area in the northwest corner of Iran and TML2 route from the eastern to the western margins of the city (Authors)

the city are mainly formed by the pyroclastic sediments including the alternating layers of volcanic ash, marl, and conglomerate. Based on the results of considering the cores of 17 drilling boreholes [33 and 39], the geology of the area along the line 2 of Tabriz Metro is mainly formed by the alluvial deposits in the areas around the eastern end of the line near Basij Square and toward the west and near Abbasi Street, which is formed by the alternating layers of claystone, siltstone, marl, and conglomerate, as well as alluvial. In the areas in the middle parts of line 2 near the great Bazar of Tabriz, in the center of the city, the geology of the area is mainly formed by the layers of siltstone, marl, and conglomerate and is covered by alluvial deposits. Finally, it is mainly formed by the alternating layers of claystone, siltstone, marl, and is covered by alluvial deposits in the areas near the western end of line 2 of Tabriz Metro (Fig. 3).

In terms of Structural Geology and Tectonics status, the study area is located along Alp-Himalaya active belt and witness many tectonized occurrences folding and faulting, which causes numerous earthquakes [28]. Therefore, Tabriz city and its surrounding areas, in the northwest of Iran, like the other parts of Iran are all seismically active and there are several large-scale active faults. According to Ambraseys and Melville [7], since 858AD the area of Tabriz has experienced at least 10 devastating earthquakes, which occurred in $858,1042,1273,1304,1550,1641,1717,1721$, 1780 and 1786 . Most of these earthquake events caused partly or totally destruction of Tabriz city with considerable number of human casualties. For example, according to Ambraseys and Melville [7], during the year 858 earthquake the old Tabriz city totally ruined and during destructive earthquakes of 1042,1780 and 1780 with magnitudes of +7 almost all parts of old Tabriz city have been entirely ruined and about 40,000 to 70,000 people have been perished. All these information about the major destructive historical earthquakes together with information about numerous minor and weaker historical earthquakes mentioned by other authors and the presence of several damaged ancient buildings in the city of Tabriz are all indication of this fact that Tabriz area has been always seismically active during the period prior to twentieth century.

Among the existing structures in the region, it can be mentioned to the major and minor faults, folding's, salt domes in the small scale, cross bedding, unconformities, etc., the most important of them is the main fault system of North Tabriz Fault (NTF). NTF in the northeastern margin of Tabriz (Figs. 3 and 4) is the most important geological structure of the study area which has great impacts on the geology, morphology and earthquake process of the region [35]. Based on the studies of Eftekhar-nezhad [20] the North Tabriz fault is an old geological fault which has been reactivated during different movements. So that, based on the studied of A'abedini and Sarmasti [8] the North Tabriz fault reactivation in the future can cause earthquakes with magnitude over 6 in the epicenter area.

Extreme earthquakes have occurred in connection with the activity of the North Tabriz fault. According to 


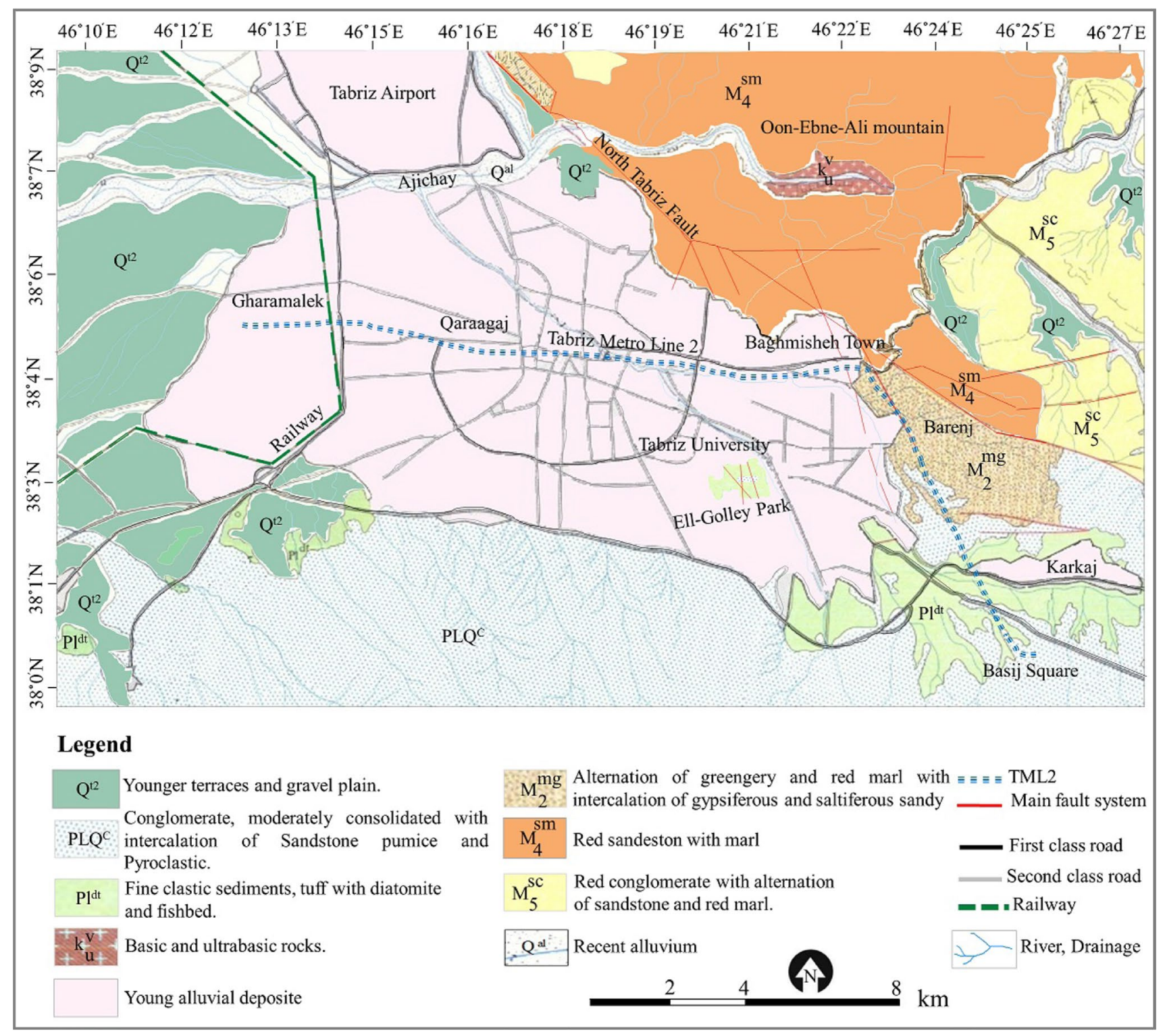

Fig. 3 The geological map of the study area and the route of TML2 (Authors)

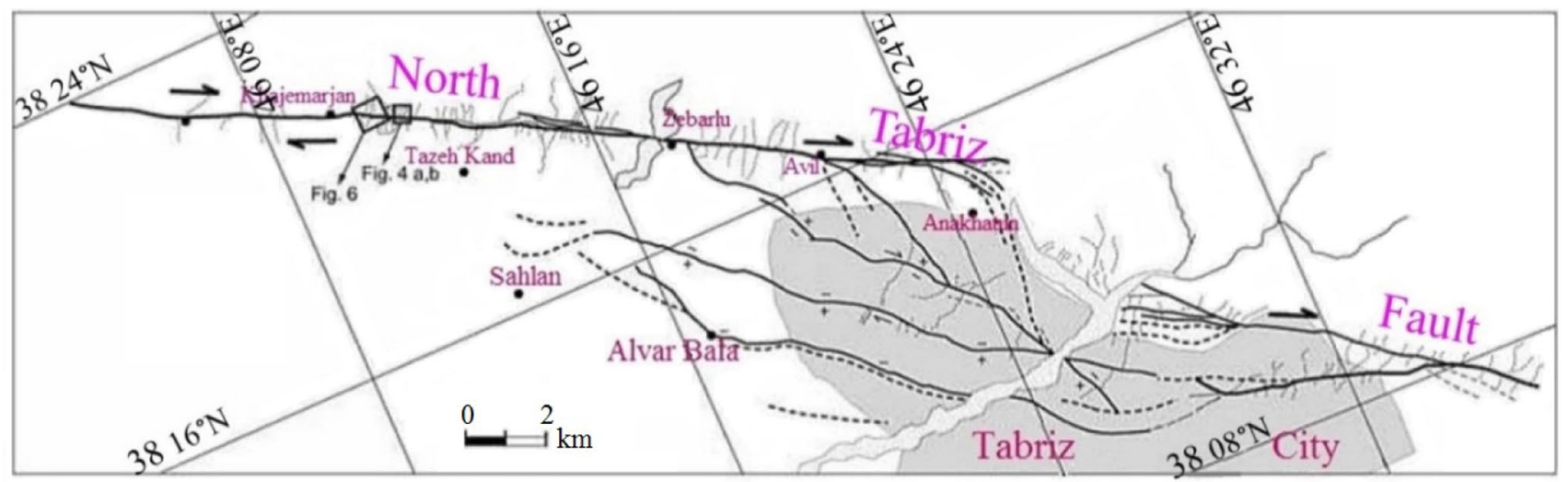

Fig. 4 North Tabriz Fault and other active faults in the northeast of Tabriz [26] 
Ambraseys and Melville [7], Berberian [12], Berberian and Yeats [13] Hessami et al. [27] earthquakes of 1042, 1721, and $1780 \mathrm{AD}$, were associated with the NTF. In addition to this fault, there are other smaller faults which according to the existing regional earthquake data are seismically active. From the other active fault near the study area, we can refer to North and South Mishow, Soufian, Dashkasan and Goijekh Faults. Eventually, according to the fault system activity and the occurred earthquakes in the region and observation of fractures in younger sediments, the area is tectonically active.

In the eastern part, between Baghmisheh town and Marzdaran town, many folds and small faults can be seen, which have caused the layers to rotate and break and displacement the layers. Figure 5 shows images of these faults and the change of bedding slope.

\subsection{Results and discussion}

\subsubsection{Route geotechnical studies}

Based on the studies of drilled boreholes and pits along the route of TML2, types and the thickness of existing soils and rocks and groundwater depth and eventually, the combination of alluvial layers at different depths in the route of metro (according to the ASTM-D-2487 standard [15]) were identified (Fig. 6 and Tables 2, 3 and 4). Accordingly, several types of soil and rock layers were recognized, which included stone-like layers, coarse-grained and fine-grained alluvial layers. Therefore ${ }_{L}$ the tunnel passes through different layers along its path.

Consistent with the results of the logs of drilled pits (Fig. 6), it was determined that the eastern part of the metro route is composed of fine-grained clay, silty and coarse-grained sediments, the central and western parts consist of coarse-grained and fine-grained alluvial sediments (areas of Ghara-aghaj) and weak rock layers of claystone, siltstone, sandstone and marlstone.

Investigation of the logs of drilled boreholes (Fig. 6) demonstrates that the western part (from the beginning of TML2 to $\mathrm{km} 3+500$ ) is composed by of the fine-grained silty and clayey alluvial sediments. At the Northern Khatib street up to Bazar area (from $\mathrm{km} \mathrm{3}+500$ to $\mathrm{km} 8+00$ ) and in the central part of the Tabriz city, the subsurface layers, generally, have been composed of coarse-grained alluvial sediments with pieces of rock (Cobble Stone and Boulder). In the areas of Mehran River (Mehran-Chay), Beheshti street and Seylab (from km $8+00$ to $\mathrm{km} 12+500$ ) along Abbasi Street, the weak rock layers of claystone, siltstone, sandstone and marlstone are observable below alluvial layers with thickness of 5 to $15 \mathrm{~m}$. Also, in the areas of Fahmideh Square up to Baghmisheh Town (from km $12+500$ to $\mathrm{km} 16+00$ ), the subsurface layers mainly have been composed of coarse-grained (Gravely-sandy) and fine-grained (clay-silty) alluvial sediments. Finally, according to these studies, at the end of eastern part of Metro
Fig. 5 Images of steep and faulted marls near L2E10 borehole in Baghmisheh town (a), Faulted marls near L2E13 borehole in Marzdaran area (b), Yellow marl around of L2E12 borehole in Barenj area (c) and Yellow and green marls in around of Baghmisheh Town (d) (Authors)

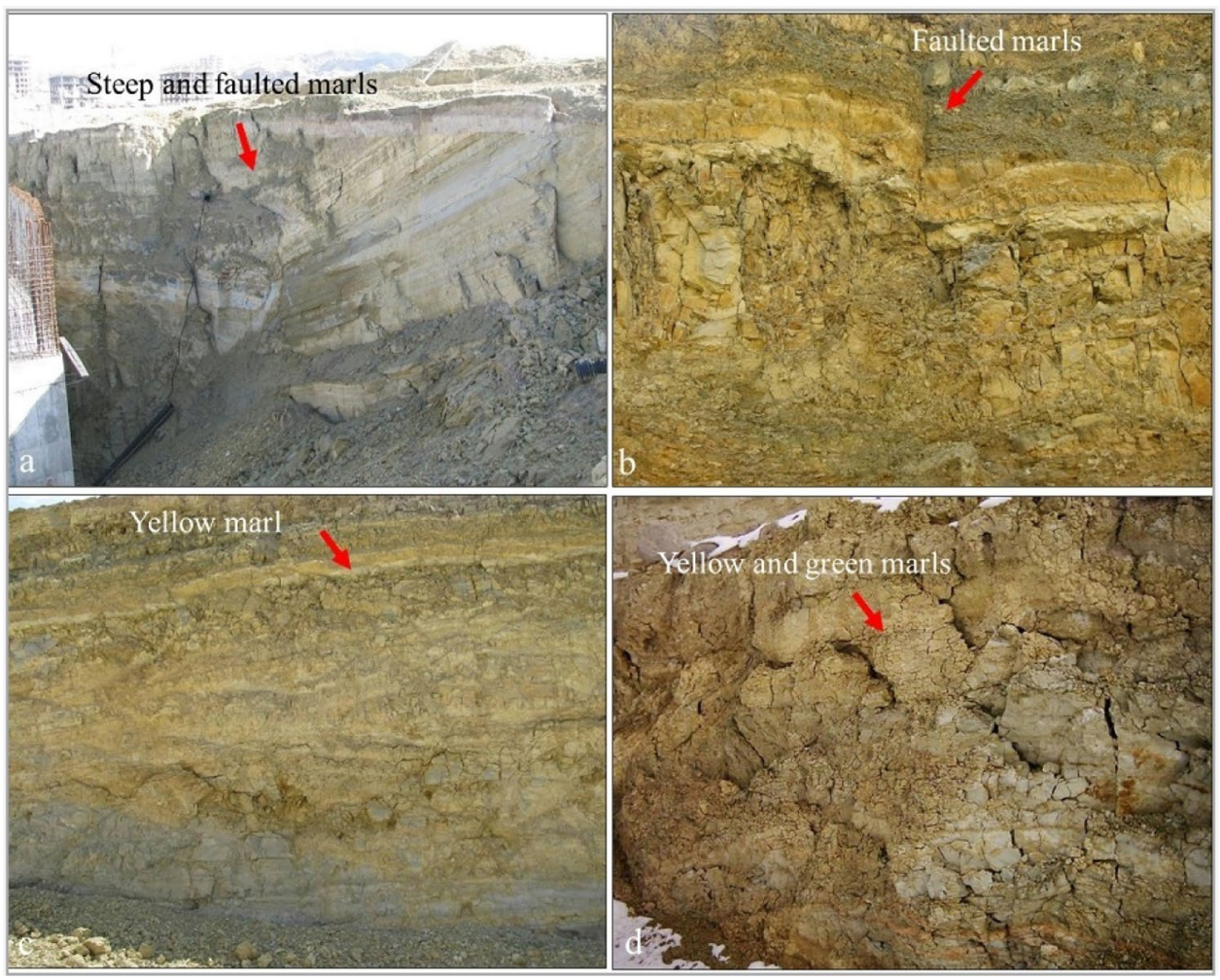




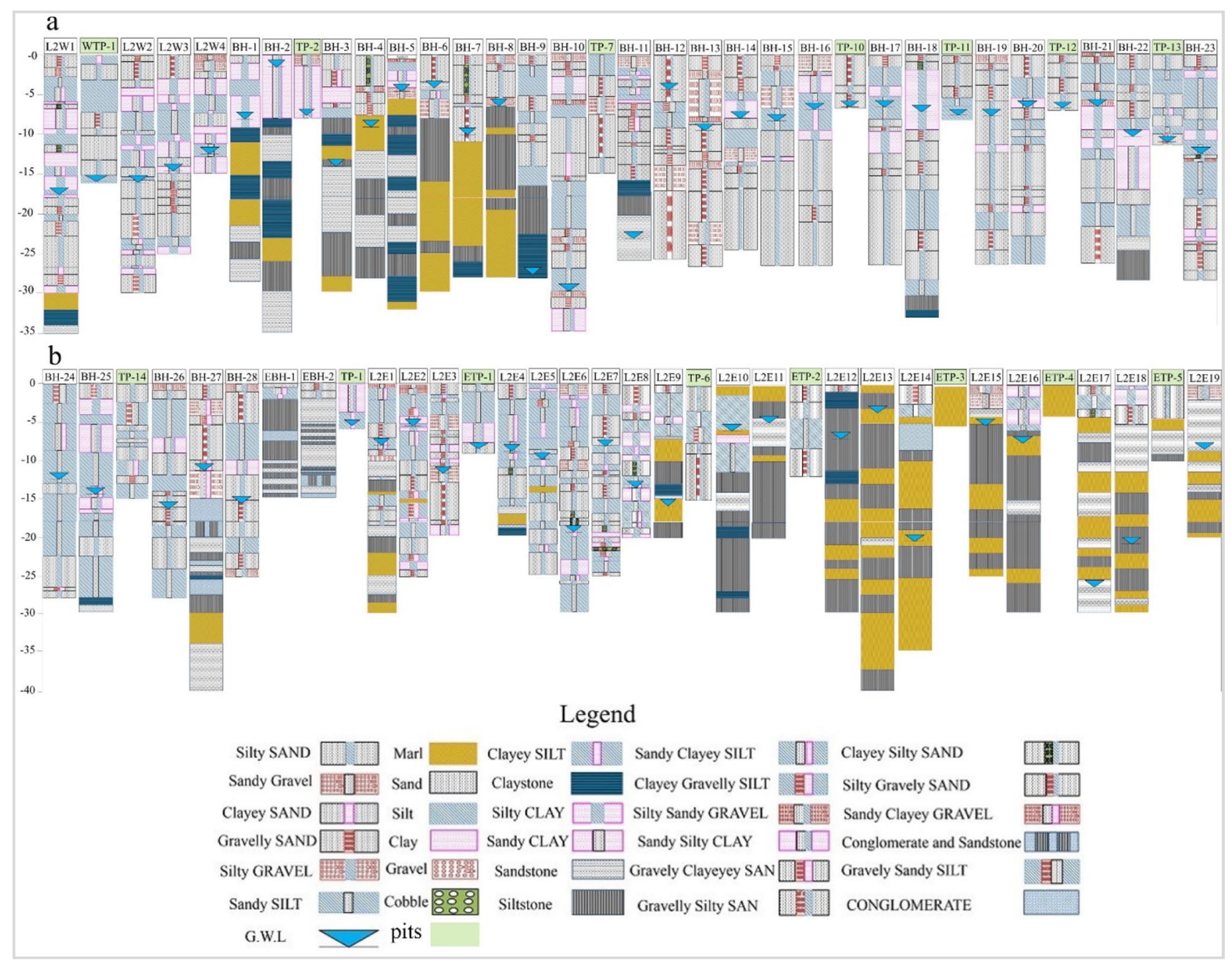

Fig. 6 Logs of drilled pits and boreholes ( $a$ and b) along the route of line 2 of Tabriz metro (Authors)

Table 2 Geotechnical specifications of alluvial layers at different depths in the western part of TML2

\begin{tabular}{llllll}
\hline \multicolumn{6}{l}{ Western part (Gharamalek-Norhern Khatib) } \\
\hline Borehole & Depth (m) & USCS & Borehole & Depth (m) & USCS \\
\hline $\mathrm{L}_{2} \mathrm{~W}_{3}$ & $7.0-8.5$ & $\mathrm{ML}$ & $\mathrm{BH}-24$ & $9.0-10.5$ & $\mathrm{ML}$ \\
$\mathrm{L}_{2} \mathrm{~W}_{2}$ & $7.0-8.5$ & $\mathrm{ML}$ & & $15.0-16.5$ & $\mathrm{ML}$ \\
& $14.0-15.5$ & $\mathrm{SM}$ & $\mathrm{BH}-23$ & $7.0-8.5$ & $\mathrm{SM}$ \\
$\mathrm{L}_{2} \mathrm{~W}_{1}$ & $7.0-8.5$ & $\mathrm{CL}$ & & $14.0-15.5$ & $\mathrm{ML}$ \\
& $14.0-15.5$ & $\mathrm{ML}$ & $\mathrm{BH}-22$ & $7.0-8.5$ & $\mathrm{SM}$ \\
$\mathrm{BH}-26$ & $10.0-11.5$ & $\mathrm{SM}$ & & $15.0-16.5$ & $\mathrm{CL}$ \\
& $14.5-16.0$ & $\mathrm{SM}$ & $\mathrm{BH}-21$ & $7.0-8.5$ & $\mathrm{CL}$ \\
& $20.0-21.5$ & $\mathrm{SM}$ & & $14.0-15.5$ & $\mathrm{SM}$ \\
$\mathrm{BH}-25$ & $7.0-8.5$ & $\mathrm{CL}$ & $\mathrm{BH}-20$ & $7.0-8.5$ & $\mathrm{SM}$ \\
& $14.0-15.5$ & $\mathrm{CL}$ & & $16.0-17.5$ & $\mathrm{SM}$ \\
\hline
\end{tabular}

route and the areas of Barenj up to Basij square (from $\mathrm{km}$ $16+00$ to $\mathrm{km} 20+00$ ), most of the existing layers have been composed of weak rock layers of claystone, siltstone, sandstone and marlstone. Accordingly, the surface and deeper layers consisted of alluvium and sedimentary rock, respectively. The thickness of alluvial layers which is the combination of clay, silt, sand and gravel, varies between 6 and $30 \mathrm{~m}$. In the continuation of these studies, the geology profile along TML2 is presented (Fig. 7).

As stated in Tables 2, 3 and 4, the combinations of alluvial layers in the western and central parts of the route of Tabriz Metro Line 2 are in group of sand (SM) and silt (ML). So that, in the areas of Northern Khatib and Mehran River (Mehran-Chay) soils of sand (SM) are observable. Also, the eastern part of the route of Metro is composed of silt (ML), sand (SM) and coarse-grained soils (GM) and in the areas of Baghmisheh Township and Marzdaran town coarsegrained soils can be seen. 
Table 3 Geotechnical specifications of alluvial layers at different depths in the central part of TML2

\begin{tabular}{|c|c|c|c|c|c|}
\hline \multicolumn{6}{|c|}{ Central part (Bazar-Fahmideh Square) } \\
\hline Borehole & Depth (m) & USCS & Borehole & Depth (m) & USCS \\
\hline BH-19 & $7.0-8.5$ & SM & $\mathrm{BH}-7$ & $8.5-10.0$ & SM \\
\hline BH-18 & $7.5-9.0$ & $\mathrm{CL}$ & & $14.0-15.5$ & $\mathrm{CL}$ \\
\hline BH-17 & $7.0-8.5$ & ML & & $19.0-20.5$ & $\mathrm{CL}$ \\
\hline $\mathrm{BH}-16$ & $7.0-8.5$ & ML & & $24.0-25.5$ & $M L$ \\
\hline $\mathrm{BH}-14$ & $7.5-9.0$ & $\mathrm{CL}$ & $\mathrm{BH}-6$ & $8.0-9.5$ & $M L$ \\
\hline $\mathrm{BH}-12$ & $8.2-9.7$ & SM & & $14.0-15.5$ & ML \\
\hline \multirow[t]{3}{*}{$\mathrm{BH}-11$} & $10.0-11.5$ & SM & $\mathrm{BH}-5$ & $6.0-7.5$ & $\mathrm{CL}$ \\
\hline & $15.0-16.5$ & SM & & $14.0-15.5$ & SM \\
\hline & $22.0-23.5$ & SM & $\mathrm{BH}-4$ & $6.0-7.5$ & SP-SM \\
\hline \multirow[t]{2}{*}{$\mathrm{BH}-10$} & $14.0-15.5$ & $\mathrm{SC}$ & & $17.0-18.5$ & $M L$ \\
\hline & 19.0-20.5 & $M L$ & $\mathrm{BH}-3$ & $6.0-7.5$ & SM \\
\hline \multirow[t]{2}{*}{ BH-9 } & $7.0-8.5$ & $\mathrm{ML}$ & & $14.5-16.0$ & SC \\
\hline & $20.0-21.5$ & $\mathrm{ML}$ & $\mathrm{BH}-2$ & $6.0-7.5$ & $\mathrm{CL}$ \\
\hline \multirow[t]{4}{*}{ BH-8 } & $7.0-8.5$ & $\mathrm{ML}$ & & $14.2-15.7$ & $\mathrm{CL}$ \\
\hline & $14.0-15.5$ & $\mathrm{ML}$ & $\mathrm{BH}-1$ & $6.0-7.5$ & $\mathrm{CL}$ \\
\hline & $18.0-19.5$ & $\mathrm{ML}$ & & $14.5-16.0$ & $\mathrm{CL}$ \\
\hline & $24.0-25.5$ & $\mathrm{CL}$ & & & \\
\hline
\end{tabular}

Table 4 Geotechnical specifications of alluvial layers at different depths in the eastern part of TML2

\begin{tabular}{|c|c|c|c|c|c|}
\hline \multicolumn{6}{|c|}{ Eastern part (Baghmisheh Town-Basij Square) } \\
\hline Borehole & Depth (m) & USCS & Borehole & Depth (m) & USCS \\
\hline \multirow[t]{3}{*}{$\mathrm{L}_{2} \mathrm{E}_{1}$} & $7.0-8.5$ & ML & \multirow[t]{2}{*}{$\mathrm{L}_{2} \mathrm{E}_{12}$} & $7.0-8.5$ & ML \\
\hline & $14.0-15.5$ & ML & & $14.0-15.5$ & $\mathrm{CL}$ \\
\hline & $22.0-23.5$ & $C L$ & \multirow[t]{3}{*}{$\mathrm{L}_{2} \mathrm{E}_{13}$} & $7.0-8.5$ & ML \\
\hline \multirow[t]{2}{*}{$\mathrm{L}_{2} \mathrm{E}_{2}$} & $6.0-7.5$ & ML & & $14.0-15.5$ & ML \\
\hline & $14.0-15.5$ & ML & & $18.0-19.5$ & $\mathrm{CL}$ \\
\hline \multirow[t]{2}{*}{$\mathrm{L}_{2} \mathrm{E}_{3}$} & $5.0-6.5$ & GM & & $24.0-25.5$ & ML \\
\hline & $14.0-15.5$ & SM & \multirow[t]{3}{*}{$\mathrm{L}_{2} \mathrm{E}_{14}$} & $7.0-8.5$ & GM \\
\hline \multirow[t]{2}{*}{$\mathrm{L}_{2} \mathrm{E}_{4}$} & $5.0-6.5$ & ML & & $14.0-15.5$ & $\mathrm{CL}$ \\
\hline & $15.0-16.5$ & SM & & $19.0-20.5$ & $C L$ \\
\hline \multirow[t]{2}{*}{$\mathrm{L}_{2} \mathrm{E}_{5}$} & $5.5-7.0$ & $M L$ & \multirow[t]{2}{*}{$\mathrm{L}_{2} \mathrm{E}_{15}$} & $5.0-6.5$ & $\mathrm{ML}$ \\
\hline & $14.0-15.5$ & $M L$ & & $14.0-15.5$ & $\mathrm{CL}$ \\
\hline \multirow[t]{3}{*}{$\mathrm{L}_{2} \mathrm{E}_{6}$} & $8.0-9.5$ & SM & \multirow[t]{3}{*}{$\mathrm{L}_{2} \mathrm{E}_{16}$} & $7.0-8.5$ & $C L$ \\
\hline & $14.0-15.5$ & SM & & $14.0-15.5$ & $\mathrm{ML}$ \\
\hline & $21.0-22.5$ & $M L$ & & $18.0-19.5$ & $\mathrm{ML}$ \\
\hline $\mathrm{L}_{2} \mathrm{E}_{7}$ & $97.0-8.5$ & SM & \multirow[t]{2}{*}{$\mathrm{L}_{2} \mathrm{E}_{17}$} & $7.0-8.5$ & $\mathrm{ML}$ \\
\hline $\mathrm{L}_{2} \mathrm{E}_{8}$ & $14.0-15.5$ & $\mathrm{CL}$ & & $18.0-19.5$ & SM \\
\hline \multirow[t]{2}{*}{$\mathrm{L}_{2} \mathrm{E}_{9}$} & $5.0-6.5$ & $M L$ & \multirow[t]{2}{*}{$\mathrm{L}_{2} \mathrm{E}_{18}$} & $7.0-8.5$ & SM \\
\hline & $15.0-16.5$ & $C L$ & & $18.5-20.0$ & $C L$ \\
\hline \multirow[t]{2}{*}{$\mathrm{L}_{2} \mathrm{E}_{10}$} & $5.0-6.5$ & $\mathrm{CL}$ & \multirow[t]{2}{*}{$\mathrm{L}_{2} \mathrm{E}_{19}$} & $5.0-6.5$ & $\mathrm{CL}$ \\
\hline & $13.0-14.5$ & $M L$ & & $13.0-14.5$ & $C L$ \\
\hline \multirow[t]{2}{*}{$\mathrm{L}_{2} \mathrm{E}_{11}$} & $5.0-6.5$ & SM & & & \\
\hline & $13.0-14.5$ & $M L$ & & & \\
\hline
\end{tabular}

Studies of variations of the groundwater depth in boreholes of the line 2 of Tabriz metro (Figs. 6 and 7) indicate that the groundwater depth in the western, central and eastern parts varies between 12.5 to $17.5,4.5$ to 30 and 1.5 to $26.5 \mathrm{~m}$ respectively. Accordingly, all boreholes of TML2 reach to the groundwater level at different depths.

\subsubsection{Results of Standard Penetration Tests (SPT)}

The purpose of the standard penetration test (SPT) is to determine the relative density and consistency of the sub-soils, and to obtain disturbed soil samples for field visual identification of soil samples. This test is the most frequently used subsurface exploration drilling test performed worldwide. In the study area, standard penetration tests (SPT) in order to evaluating the density of soil and rock were performed in all of the drilled boreholes at $1.5 \mathrm{~m}$ intervals. All of these tests have been carried out according to the ASTM D1586 standard [1]. In this research from 53 drilled boreholes up to $40 \mathrm{~m}$ depth by the continuous rotary coring technique were used. Figures 8 and 9 demonstrate the results of variation of SPT-N with depth and the trend lines SPT-N/depth in the drilled boreholes in the route of $T M L 2$, respectively.

As it is clear from Figs. 8 and 9, the SPT number increases with depth, so that in most of the boreholes from depth of about $24 \mathrm{~m}$, the SPT number is generally more than 50 , thus, it means that the density of soil increases by increase in depth and for this reason soils of the study area are classified as medium to very high compacted soils.

According to the results of standard penetration test, the SPT number also increases from western parts of TML2 to its eastern parts again from and the standard penetration test values (N-SPT) [9], the soils of western parts (Gharamalak-Ghara Aghaj area) are classified in the group of dense to very dense, the soils of central parts and areas of Bazar and Fahmideh are very dense and dense, respectively, and soils of Baghmisheh township and Basij square, the eastern parts of the study area are classified in the group of very dense (Fig. 8).

\subsubsection{Investigation of the existing sulfate values}

Harmful chemical materials of soil can have destructive effects on concrete structures buried in the soil, which can cause problems in structures such as tunnels and stations over a long period of time. One of these harmful chemical materials of soil is sulfates. Damage caused by sulfate is one of the new problems which reduces age of concrete structures. This failure causes the volume increase in concrete crystals with respect to the volume of the raw material of the concrete, increases, which causes pressure in the concrete cavities and as a result causes cracks in it. 


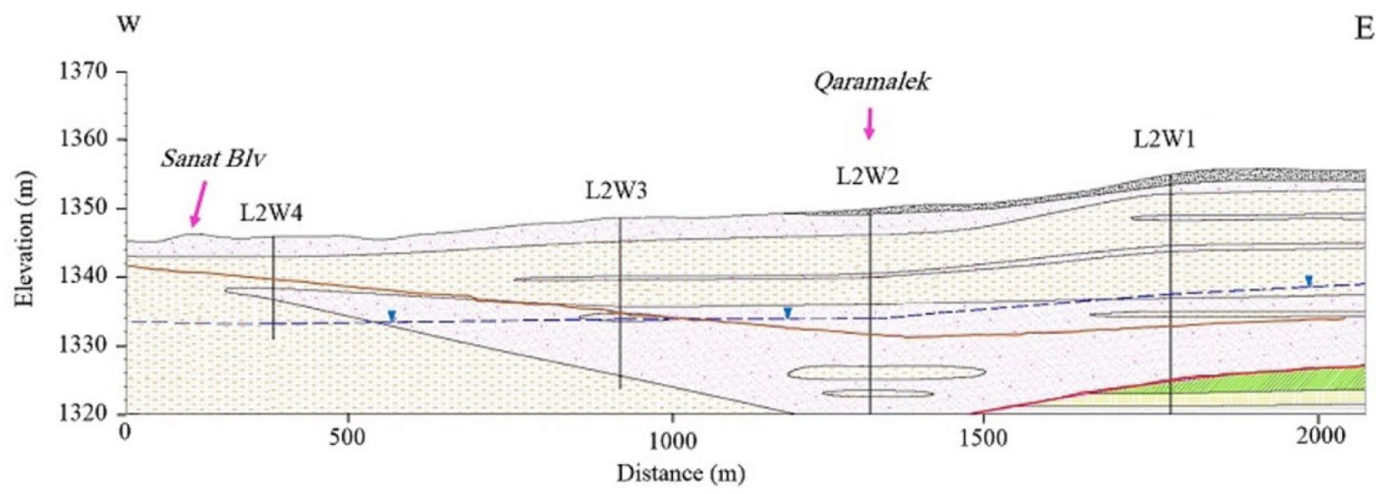

W

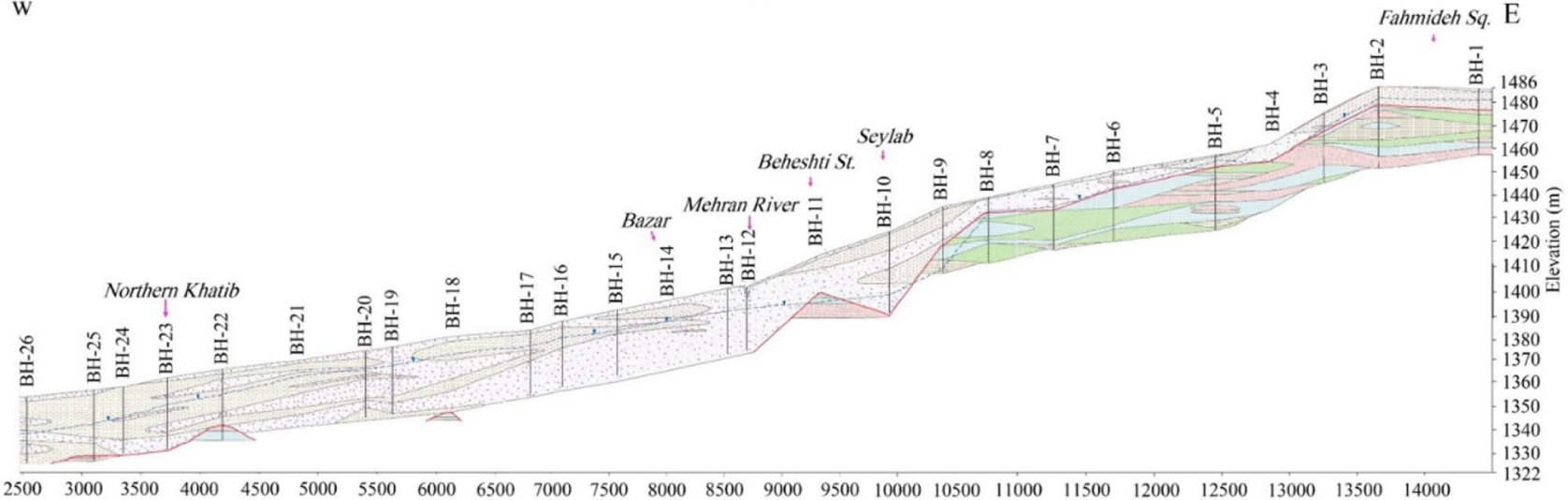
Distance (m)

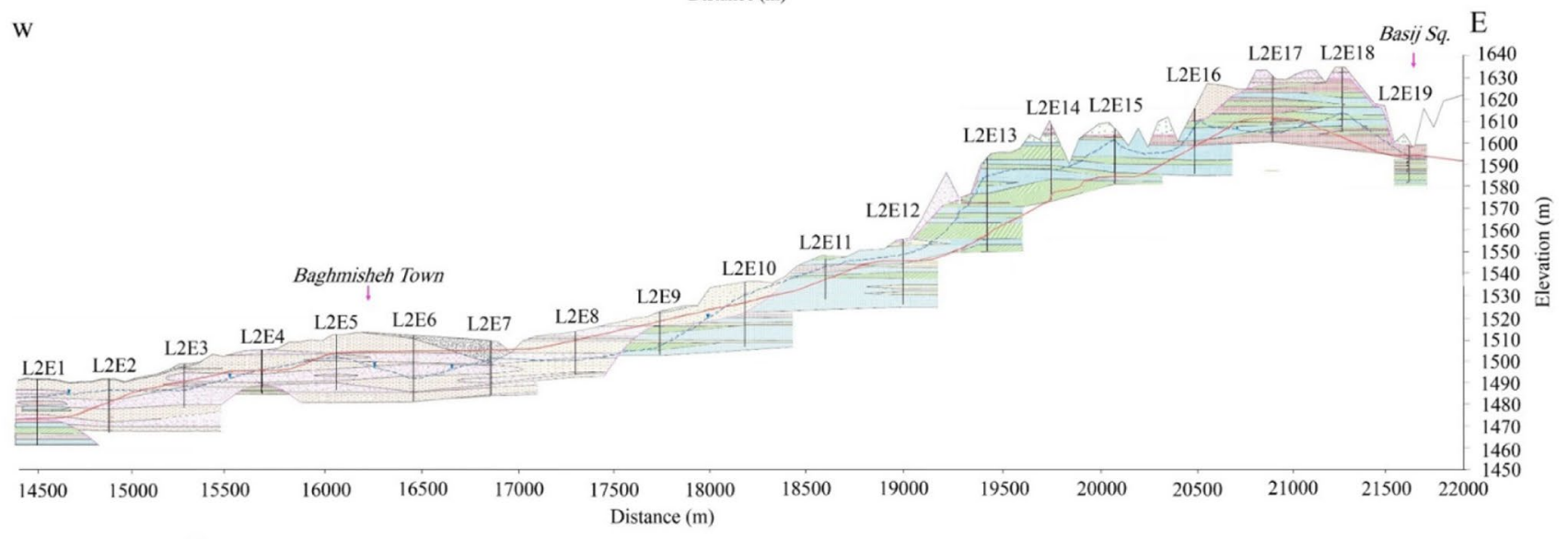

\section{Legend}

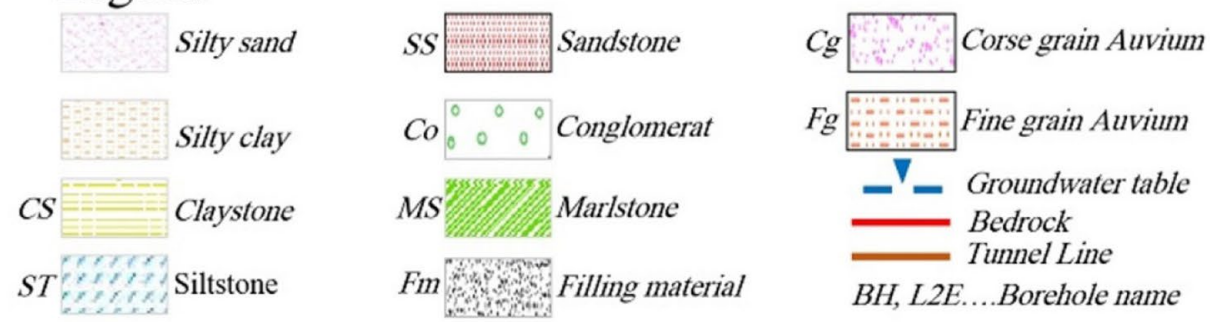

Fig. 7 Geology profile along TML2 (Authors)

Therefore, sulfate attacks in concrete are one of the factors that may reduce the useful age of the structure in the long term, so that its repair is not easily possible. Accordingly, in the study area chemical analysis tests were performed on 100 samples.

In order to investigate the amount of soluble sulfate in the boreholes of the route of line 2 Tabriz Metro, 


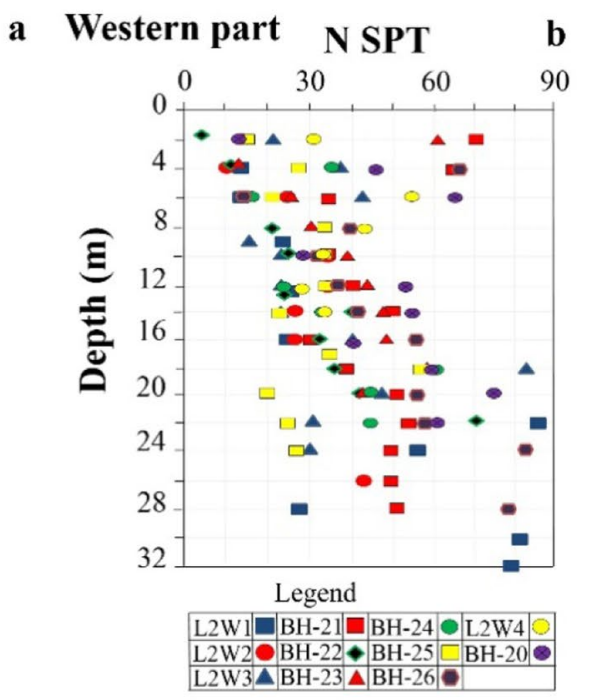

\section{Central part N SPT}

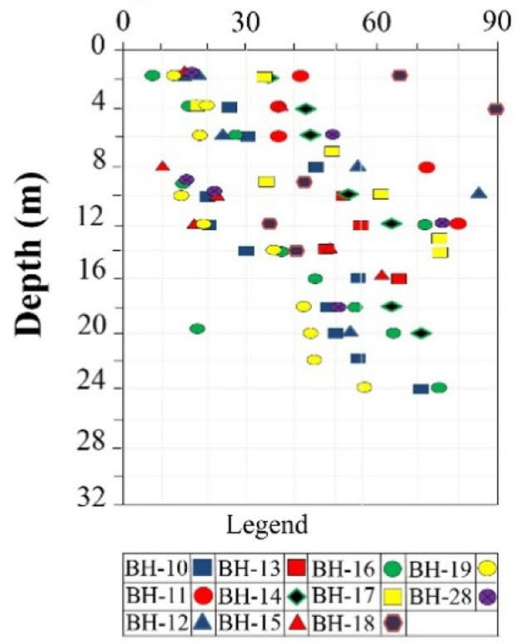

c Central part N SPT

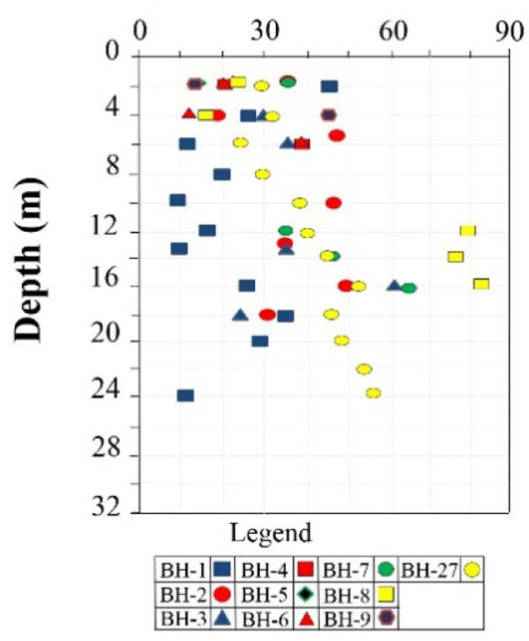

\section{d Eastern part N SPT}

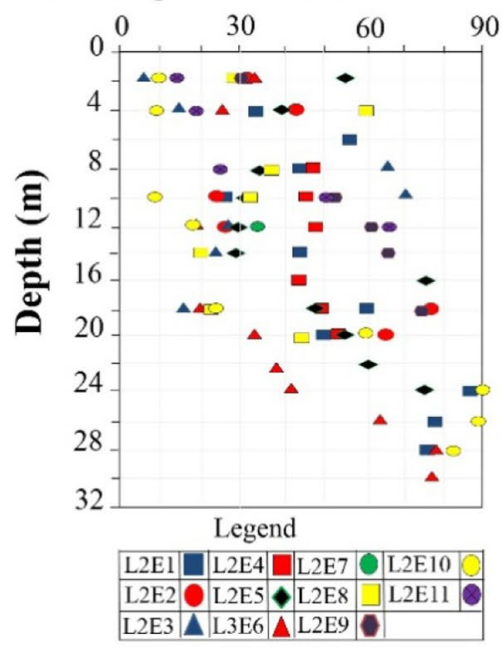

e Eastern part N SPT

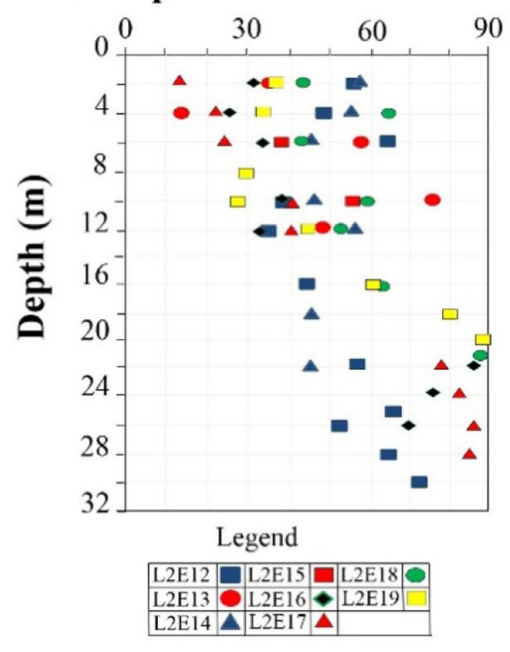

Fig. 8 Variation of SPT-N with depth along the TML2: a Western, b, c Central and d, e Eastern parts (Authors)

Fig. 9 The trend lines SPT-N/ depth in the route of TML2 (Authors)

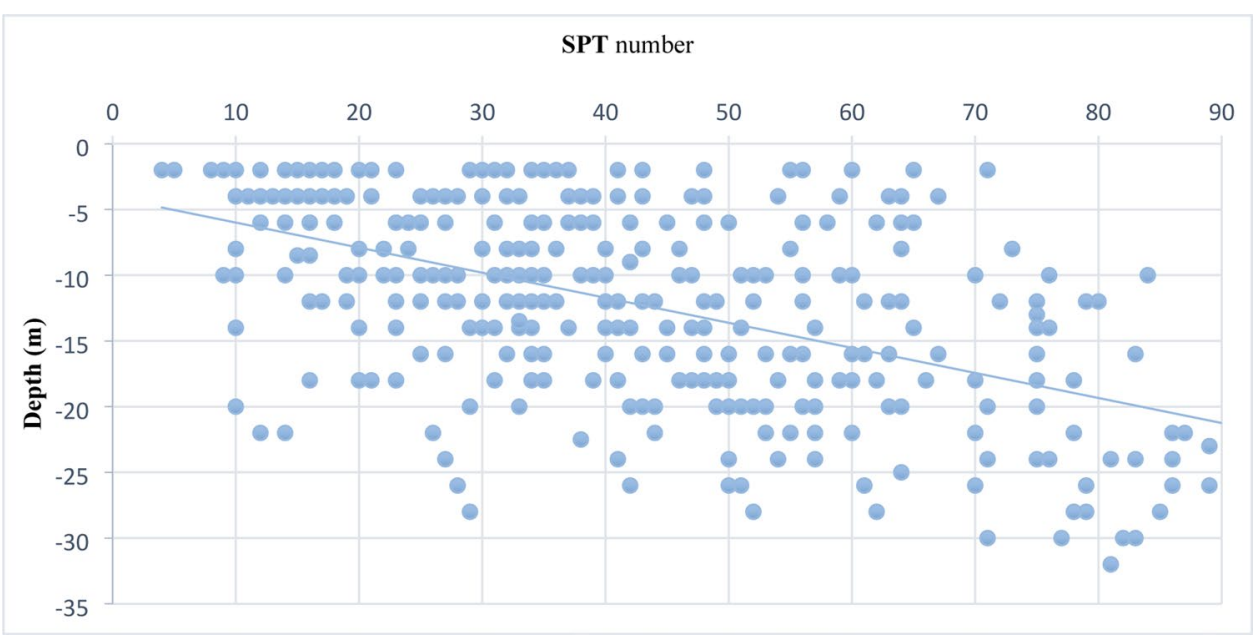


according to Concrete Code of Iran (CCI) [36], the amount of sulfate was evaluated. Summary of the results of these studies is presented below (Table 5).

According to the results of conducted tests, the amount of sulfate in the soil is between 200 and $26,500 \mathrm{ppm}$. Accordingly, the amount of soluble sulfate in the soils of the western (Qaramalek, Qara Aghaj and Bagheh Golestan areas), central (Bazar, Sheshgelan and Fahmideh areas) and eastern parts (areas of Baghmisheh Town, Barenj and Basij Square) of the route of TML2 varies, respectively, 200 to $1300 \mathrm{ppm}, 200$ to $3600 \mathrm{ppm}$ and 200 and 26,500 ppm. Also, based on this investigations the average of sulfate in the western, central and eastern parts is, respectively, 1118, 1275 and 4840 ppm (Table 5). In the continuation of these studies, zoning of boreholes of TML2 in terms of the amount of soluble sulfate is shown in Fig. 10.

As can be seen in Fig. 10, the amount of soluble sulfate in the soil is mild to extremely high. Accordingly, the amount of sulfate increases from the western to the eastern parts. So that the amount of sulfate in the central parts is less than $1300 \mathrm{ppm}$ while in the eastern parts this value reaches to $5000 \mathrm{ppm}$. Even in boreholes of L2E12, L2E13, L2E14, L2E16, L2E18 and L2E19 in the areas of Baranj, Marzdaran town and Basij Square this value reaches up to $26,500 \mathrm{ppm}$ and extreme conditions in terms of soluble sulfate. It should be noted that the high sulfate ion in the eastern parts is due to the presence of gypsum soils and gypsum veins in the existing fractures. So that, subsurface section investigations (drilled boreholes and pits), the type
Table 5 Summary of the amount of soluble sulfate in the soil in the route of Tabriz Metro Line 2 (Authors)

\begin{tabular}{llrl}
\hline Area & $\mathrm{SO}_{4}^{-2}(\mathrm{ppm})$ & $\begin{array}{l}\text { Mean } \\
\text { of } \mathrm{SO}_{4}^{-2} \\
(\mathrm{ppm})\end{array}$ \\
\hline Western Part (Gharamalek, Qara Aghaj and Bagheh Gholestan areas) & Maximum & 1300 & 1118 \\
& Minimum & 200 & \\
Central Part (Bazar, Sheshgelan and Fahmideh areas) & Maximum & 3600 & 1275 \\
Eastern part (areas of Baghmisheh Town, Barenj and Basij Square) & Minimum & 200 & \\
& Maximum & $\begin{aligned} 26,500 \\
\text { Minimum }\end{aligned}$ & 200 \\
\end{tabular}

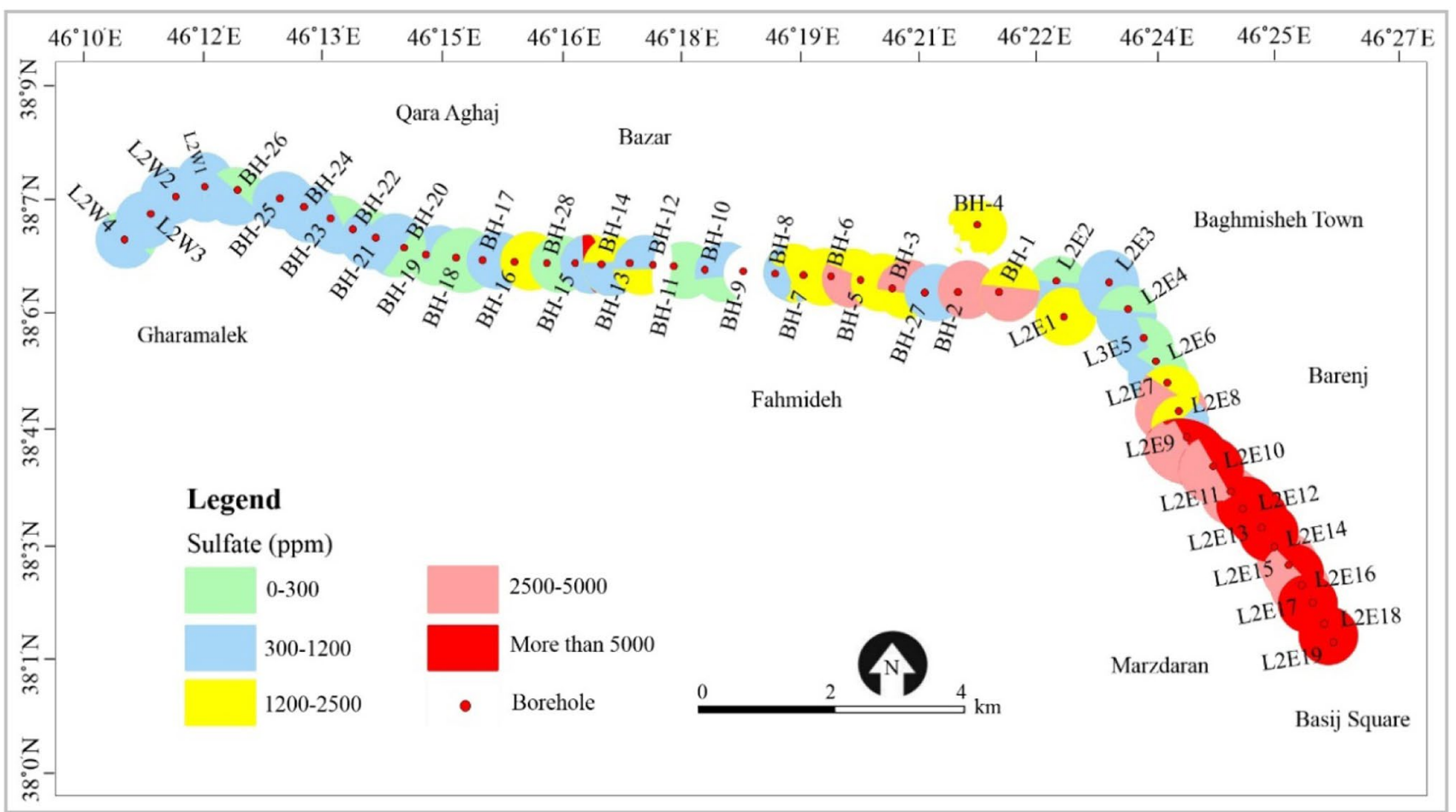

Fig. 10 Zoning of boreholes of line 2 of Tabriz Metro in terms of the amount of soluble sulfate (Authors) 
and thickness of existing soils and rocks (Figs. 6 and 7) indicate that these areas composed of sediments of yellow and green marls and layers of gypsum. Therefore, it is suggested that in this part of the tunnel route, in order to improve the resistance of concrete against sulfate attack, various types of additives including microsilica, zeolite, fly ash, metakaolin and nanosilica should be used as a substitute for cement.

\subsection{Conclusions}

The present study conducted in order to determine the engineering geology and geotechnical details of soils and rocks along the line 2 of Tabriz metro by using the information and raw data which were acquired by borehole drilling and all field and laboratory tests, such as the results of STP in situ tests and the results of laboratory tests, such as physical and chemical properties of soils and rocks along the line 2 of Tabriz metro.

The results of considering geological setting of study area revealed that the areas along TML2, mainly formed by alternating layers of claystone, siltstone, marl, and conglomerate, covered mainly by the alluvial deposits and in addition to older, dextral, strike-slip North Tabriz Fault (NTF) which is a major and most important geological structure of Tabriz area, there are also many minor and generally young and seismically active faults. The results of investigation on the groundwater depth in boreholes of TML2 also indicated that the groundwater depth varies between 12.5 and $17.5 \mathrm{~m}$, in the western parts, between 4.5 and $30 \mathrm{~m}$, in the central parts, and between 1.5 and $26.5 \mathrm{~m}$ in the eastern parts. The results of performing standard penetration tests (SPT) in order to evaluating the density of soil and rock, which performed in all of the drilled boreholes at $1.5 \mathrm{~m}$ revealed that soils of the western parts of TML2 are in the group of dense to very dense, the central parts are in the group of very dense (Bazaar area) and dense (Fahmideh area), and the eastern parts are very dense. Therefore, according to the results of SPT values in the western and central parts, all of the safety measures should be taken into account for designing and construction of tunnels of these zones and insure their long-term stability. And finally the results achieved from determining groundwater sulfate values according to Concrete Code of Iran (CCI) [36], indicated that the amount of soluble sulfate in the soil is mild to extremely high. Accordingly, the amount of sulfate increases from the western to the eastern parts. So that, this values is between 200 and $26,500 \mathrm{ppm}$. Based on these studies, the amount of soluble sulfate in the soils of the western (Qaramalek, Qara Aghaj and Bagheh Golestan areas), central (Bazar, Sheshgelan and Fahmideh areas) and eastern parts (areas of Baghmisheh Town, Barenj and Basij Square) of the route of TML2 varies, respectively, 200 to $1300 \mathrm{ppm}, 200$ to $3600 \mathrm{ppm}$ and 200 and $26,500 \mathrm{ppm}$. Also, the average of sulfate in the western, central and eastern parts is, respectively, 1118,1275 and $4840 \mathrm{ppm}$. Therefore, due to the high amounts of soluble sulfate within the eastern part, it is recommended that the Concrete Code of Iran (CCI) should be observed more precise and for increasing resistance of soils and rocks of these zones against sulfate attacks, various types of additives including Micro Silica, Zeolite, Fly ash, Metakaolin and Nanosilica should be used as a substitute for some cement.

\section{Compliance with ethical standards}

Conflict of interest The authors have no conflicts of interest.

Open Access This article is licensed under a Creative Commons Attribution 4.0 International License, which permits use, sharing, adaptation, distribution and reproduction in any medium or format, as long as you give appropriate credit to the original author(s) and the source, provide a link to the Creative Commons licence, and indicate if changes were made. The images or other third party material in this article are included in the article's Creative Commons licence, unless indicated otherwise in a credit line to the material. If material is not included in the article's Creative Commons licence and your intended use is not permitted by statutory regulation or exceeds the permitted use, you will need to obtain permission directly from the copyright holder. To view a copy of this licence, visit http://creativecommons. org/licenses/by/4.0/.

\section{References}

1. ASTM D1586 (2011) Standard test method for standard penetration (SPT) and Split-barrel sampling of soils. In: American Society for Testing and Materials. Philadelphia, USA

2. Azali S, Ghafoori M, Lashkaripour Gh, Hassanpou J (2013) Engineering geological investigations of mechanized tunneling in soft ground: A case study, East-West lot of line 7. Tehran Metro, Iran. https://doi.org/10.1016/j.enggeo.2013.07.012

3. Asadian AO (2017) Geological map of Tabriz, 1:100000 Scale, Geological Survey of Iran. https://gsi.ir/tabriz/fa (in Persian)

4. Azarafza M, Akgün H, Asghari-Kaljahi E (2018) Stochastic geometry model of rock mass fracture network in tunnels. Q J Eng GeolHydrogeol. https://doi.org/10.1144/qjegh2017-136

5. Agha-Nabati A (2007) Geology of Iran. Geological Survey of Iran press, Tehran, Iran

6. Azarafza M and Ghazifard A (2016) Urban geology of Tabriz City: Environmental and geological Constraints, Advances in Environmental Research, Vol. 5, No. 2. https://doi.org/10.12989/aer. 2016.5.2.095

7. Ambraseys NN, Melville CP (1982) History of Persian Earthquakes, Cambridge Earth Science Series. Cambridge University Press, London. p212. https://www.amazon.com/History-Persi an-Earthquakes-Cambridge-Science/dp/0521021871

8. Abedini M, Sarmasti N (2016) Seismic Power of Tabriz Fault and Casualties in Tabriz Metropolitan Assessment by Experimental Models and GIS. J Geogr Earth Sci. https://doi.org/10.15640/ jges.v4n1a3 
9. Bowels J (1988) Foundation analysis and design. McGraw Hill International Book Company 1988:1004

10. Babazadeh R (2010) Engineering geological studies of Tabriz urban railway line 2, with emphasis on soil liquefactio. M. Sc Thesis, Bu-Ali Sina university, Hamedan-Iran (IN Persian) 162.

11. Barzegari Gh, Uromiehy A, Zhao J (2014) EPB tunneling challenges in boulder ground: new experience on Tabriz Metro Line 1. Iran Bull Eng Geol Environ 73:429-440

12. Berberian M (1997) Seismic sources of the Transcaucasian historical earthquakes. In: Giardini D, Balassanian S (eds) Historical and prehistorical earthquakes in the Caucasus, pp $233-311$. Kluwer, Dordrecht.

13. Berberian M and Yeats R. S (1999) Patterns of historical earthquake rupture in the Iranian plateau. Bull Seismol Soc Am 89:120-139. https://pubs.geoscienceworld.org/ssa/bssa/.

14. Babakhani et al (1991) Description of Ahar geological map, Geological Survey of Iran,p 130.

15. Classification of Soils for Engineering Purposes: Annual Book of ASTM Standards, D 2487-83, 04 (archived from the original on 2010-09-14, retrieved 2015-05-08) American Society for Testing and Materials, 1985, pp. 395-408.

16. Cueto M, Puente P, Lopez-Fernandez L, Pando L, Arias D (2018) Karst detection, prevention and correction: a case study along the Riyadh Metro Line 3 (Saudi Arabia). Presented at the 2nd International Research Conference on Sustainable Energy, Engineering, Materials and Environment (IRCSEEME), Mieres, Spain.

17. Cueto M, Lopez-Fernandez C, Pando L, Arias D (2020) Engineering geological assessment using geochemical, mineralogical, and petrographic analysis along the Riyadh Metro Line 3 (Saudi Arabia). Arab J Geosci. https://doi.org/10.1007/ s12517-020-5091-8

18. Das BM (1983) Advanced soil mechanics. McGraw-Hill Book Company

19. Delezalova M (2002) Approaches to numerical modeling of ground movements due to shallow tunneling. In: Proceedings of international symposium on soil structure interaction in urban civil engineering. Swiss Federal Institute of Technology, Zurich, pp 365-373.

20. Eftekhar-nezhad H (1975) Brief description of tectonic history and structural development of Azarbaidjan. Geological Survey of Iran (Int. report)

21. Golpasand M, Nikudel M, Uromeihy A (2014) Effect of engineering geological characteristics of Tehran's recent alluvial on ground settlement due to tunneling. Geopersia 4 (2), PP. 185-199, https://doi.org/10.22059/JGEOPE.2014.52718.

22. Ghiasi $V$ et al (2011) Subway station seismic consideration based on geotechnical study: a case study approach. Sci Res Essays 6(9):1940-1956. http://www.academicjournals.org/SRE

23. Ghobadi MH, Firuzi M, Asghari E (2016) Relationships between geological formations and ground water chemistry and their effects on concrete lining of tunnels (case study: Tabriz Metro Line 2). Environ Earth Sci 75:2-14

24. Ghasemian M, Dabiri R, Mahari R (2017) Settlements Hazard of Soil Due to Liquefaction along Tabriz Metro Line 2. Research Bulletin of Seismology and Earthquake Engineering (In Persian).
25. Haghshenas E, Jafari M (2006) Preliminary results of site effect assessment in the City of Tabriz (Iran) Using Earthquake Recordings. In: Third international symposium on the effects of surface Geology on Seismic Motion, Grenoble, France, pp 106-115.

26. Hessami Kh, Pantosti D, Tabassi H, Shabanian E, Abbassi MR, Feghhi Kh, Solaymani Sh (2003) Paleoearthquakes and slip rates of the North Tabriz Fault, NW Iran: preliminary results. Ann Geophys 46:903-917. https://doi.org/10.4401/ag-3461

27. Hessami K, Jamali $F$ (2008) New evidence of earthquake faulting in Tabriz city. NW Iran Geosci 17(1):156-161

28. International Institute of Earthquake Engineering and Seismology (2017) Earthquake data of Tabriz city in 200 km radius, Earthquake catalogue of Tabriz city, http://www.iiees.ac.ir

29. Leca E, New B (2007) Settlements induced by tunneling in Soft Ground. Tunnel Underground Space Technol 22:119-149

30. Mitew-Czajewska M (2015) Geotechnical investigation and static analysis of deep excavation walls - a case study of metro station construction in Warsaw, Institute of Roads and Bridges, Annals of Warsaw University of Life Sciences-SGGW Land Reclamation. http://www.ann_landreclam.sggw.pl/

31. Mohammadi SD, Firuzi M, Asghari Kaljahi E (2015) Geological and geotechnical risk in the use of EPB-TBM, case study: Tabriz Metro. Iran Bull Eng Geol 75:1571-1583

32. Ozsan Y, Basarir H Cilsal M (2006) Engineering geological investigations along the Ankara subway extension. Conference: IAEG, https://www.researchgate.net/publication/293452340.

33. Omran Rahvar (POR) Consulting Engineers Company (2008) Final Report of Preliminary Geotechnical Investigation Tabriz Urban Railway Line 2. http://rahvar-co.com/fa/ (in Persian)

34. Oshnaviyeh D, Dabiri R (2017) Comparison of Standard Penetration Test (SPT) and Shear Wave Velocity (Vs) method in determining risk of liquefaction potential along Tabriz Metro Line 2. Journal of Engineering Geology, Kharazmi University (in Persian, in press).

35. Porkermani M, Aryan M (1998) Seismicity of Iran. Shahid Beheshti University Press, Tehran, Iran. http://library.sharif.ir/ parvan/resource/274045/ (in Persian)

36. Plan and Budget Organization of Iran (2018) Concrete Code of Iran (CCI) https://www.mporg.ir

37. Rieben $\mathrm{H}$ (1965) Contribution to the geology of Persian Azerbaijan, These presentce at the faulte des sciences of the University of Neuchatel, to obtain the degree of Doctor of Science. Neuchate I Imprimerie Central, S. A., p 142

38. Sadjadi F, Bagherzadeh Khalkhali A (2018) Geotechnical Challenges of Tehran Metro Line 7 (South Northern Route). Civil Eng J. www.CivileJournal.org

39. TURO (2007) Engineering geological and geotechnical Investigation Reports, Line 2. Tabriz Urban and Railway Organization, 263.

Publisher's Note Springer Nature remains neutral with regard to jurisdictional claims in published maps and institutional affiliations. 